\title{
Use of anti-HIV immunotoxins as probes of the biology of HIV-infected cells
}

\author{
Seth H PINCUS MD, JAN MCCluRE MS, HUA FANG MD
}

\begin{abstract}
SH Pincus, J MCClure, H Fang. Use of anti-HIV immunotoxins as probes of the biology of HIV-infected cells. Can J Infect Dis 1994;5(Suppl A):23A-27A.
\end{abstract}

OвJестіve: Anti-human immunodeficiency virus (HIV) immunotoxins are potential treatments for HIV infection, but they may also be used as probes to study the relationship between HIV and the cell it infects. Data from the present study indicate the complexity of this relationship.

Design: A panel of monoclonal antibodies directed against different epitopes on the HIV envelope protein(s) gp120 and gp41 was conjugated to ricin A chain. The activity of these immunotoxins on HIV-infected cell lines was studied.

Results: The data demonstrate that HIV-infected cell lines may be killed by some, but not all, of these immunotoxins. The killing is not directly proportional to the binding of the antibody to the infected cell and is influenced by the viral strain. The immunotoxins were used to select persistently infected cell lines for immunotoxin-resistant variants; these demonstrate several different viral or cellular defects. The incubation of infected cells with a soluble form of the viral receptor increases the sensitivity of the cells to anti-gp41, but not anti-gp120, immunotoxins by altering both the levels of expression and internalization of the viral envelope. Drugs that inhibit lysosomal degradation (ammonium chloride, monensin, chloroquine) enhance the efficacy of these immunotoxins.

Conclusions: Because immunotoxins must be internalized to function, they may be used to study the intracellular trafficking of the target antigens. In the present study, this was done using the HIV-envelope protein as expressed in infected cells as the target antigen.

Key Words: AIDS therapy, gp41, gp120, Human immunodeficiency virus, Immunotoxin, Ricin

\section{Emploi des immunotoxines anti-VIH pour sonder la biologie des cellules infectées au VIH}

OвJECTIF : Les immunotoxines antivirus de l'immunodéficience humaine (VIH) sont un traitement potentiel contre l'infection au VIH, mais elles peuvent également être utilisées comme sonde pour étudier le rapport entre le viH et la cellule qu'il infecte. Les données tirées de la présente étude signalent la grande complexité de ce lien.

MoDèle : Une série d'anticorps monoclonaux dirigés contre différents épitopes des protéines de l'enveloppe du VIH gp 120 et gp 41 a été conjuguée à une chaîne A de ricin. L'activité de ces immunotoxines sur les lignées cellulaires infectées au VIH a été étudiée.

RÉSultats : Les données démontrent que les lignées cellulaires infectées au VIH peuvent être détruites par certaines mais non pas par toutes ces immunotoxines. La destruction n'est pas directement proportionnelle au degré de liaison de lanticorps à la cellule infectée, et est influencée par la souche virale. Les immunotoxines ont été utilisées pour sélectionner les lignées cellulaires chroniquement infectées à l'égard des variantes résistantes aux immunotoxines. Celles-ci manifestent plusieurs anomalies virales ou cellulaires différentes. L'incubation des cellules infectées à l'aide d'une forme soluble du récepteur viral augmente la sensibilité des cellules aux immunotoxines anti-gp 41, mais non pas aux immunotoxines anti-gp 120, en influant sur le taux d'expression et d'assimilation de l'enveloppe virale. Les médicaments

Laboratory of Microbial Structure and Function, NIAID Rocky Mountain Laboratories, Hamilton, Montana; and Bristol-Myers Squibb Pharmaceutical Research Institute, Seattle, Washington, USA

Correspondence and reprints: Dr SH Pincus, Laboratory of Microbial Structure and Function, NIAID Rocky Mountain

Laboratories, Hamilton, MT 59840, USA. Telephone (406) 363-9317, Fax (406) 363-9204 
qui inhibent la dégradation lysosomique (chlorure d'ammonium, monensin, chloroquine) rehaussent l'efficacitê de ces immunotoxines.

Conclusions : Parce que les immunotoxines doivent être assimilées pour fonctionner, elles peuvent servir à étudier les déplacements intracellulaires des antigènes-cibles. Dans la présente étude, cela a été effectué par l'entremise de protéines de l'enveloppe du viH, telle qu'elles s'expriment dans les cellules infectées sous la forme d'antigènes-cibles.

$\mathrm{T}$ HE HUMAN IMMUNODEFICIENCY VIRUS (HIV) ENVELOPE protein(s) are expressed on the surface of HIVinfected cells. These proteins consist of a precursor protein (gp160), which is cleaved into extracellular (gp120) and transmembrane (gp41) portions. Much of this protein is associated with budding virions. It is less well appreciated that a proportion of the envelope proteins is internalized from the cell surface. The processes of envelope protein synthesis, assembly and cellular trafficking are not yet fully understood.

The present study explored the potential of anti-HIV immunotoxins as therapeutic reagents (1-3). These immunotoxins consist of anti-gp 160 antibodies coupled to ricin A chain (RAC). Other anti-HIV immunotoxins consist of the viral receptor, $\mathrm{CD} 4$, coupled to one of several different toxins (4-6). These immunotoxins kill HIVinfected cells in vitro. In vivo they would function by eliminating cells that are actively secreting viral proteins, thereby eliminating the nidus of infection.

Ricin immunotoxins kill target cells following internalization. Once inside the cell, the linkage between the antibody and RAC is cleaved. The free RAC functions in the cytosol to cleave the $28 \mathrm{~S}$ ribosomal RNA and to halt protein synthesis. This results in the death of the cell. Because immunotoxins must be internalized to function, they may be used as probes to study the cellular trafficking of the target antigen. The best evidence that exists demonstrating that the HIV envelope protein is internalized is that even monovalent HIV-specific immunotoxins function to kill infected cells. The only way for monovalent immunotoxins to enter and kill the cell is for the ligand to which the immunotoxin is attached to be internalized, most likely as part of its cellular trafficking. In the present study, a panel of anti-HIV immunotoxins was used to study the cellular trafficking of the HIV envelope proteins. A number of factors was found to be able to influence the internalization and intracellular routing of these immunotoxins.

\section{MATERIALS AND METHODS}

Antibodies, immunotoxins, Hrv strains and cell lines: The antibodies and immunotoxins used in this study have been described in detail elsewhere (2). The antibodies are listed in Table 1. Immunotoxins were constructed by coupling the indicated antibody to purified RAC using the heterobifunctional cross-linker $\mathrm{N}$-succinimidyl-3-(2-pyridyldithio) propionate. This cross-linker contains a disulfide bond that is broken upon reaching the reducing conditions found within the cell. The immunotoxin $\mathrm{CD} 4-\mathrm{PE} 40$, a chimeric protein consisting of the

\section{TABLE 1}

Antibodies used in the study

\begin{tabular}{|c|c|c|}
\hline Antibody & Species & Specificity \\
\hline $\mathrm{T7}$ & Mouse & Irrelevant antigen \\
\hline 924 & Mouse & $\begin{array}{l}\text { gp120, V3 loop, amino acids } \\
\text { 313-324 }\end{array}$ \\
\hline 41.1 & Mouse & gp41, amino acids 579-604 \\
\hline 41.4 & Human & gp41, amino acids 579-604 \\
\hline 110.1 & Mouse & gp 120, amino acids $400-417$ \\
\hline Anti-gp 160 & Human & $\begin{array}{l}\text { gp 160, affinity purified } \\
\text { polyclonal antibody }\end{array}$ \\
\hline
\end{tabular}

two amino-terminal domains of $\mathrm{CD} 4$ fused to a truncated form of pseudomonas exotoxin lacking the binding domain (4), was obtained from Upjohn Laboratories (Michigan). Persistently HIV-infected cells were established using the molecular clone NL4-3 to infect the H9 $\mathrm{T}$ cell line $(2,7)$. Acute infections were established in A3.01 cells with a variety of strains of HIV and then adding fresh uninfected cells to the infected cell culture weekly at a ratio of 10 uninfected cells to one infected (2). Functional assays of immunotoxin action: The effects of the immunotoxins on infected cells were assayed in two ways: by cytotoxicity and by inhibition of production of infectious HIV. Details of these assays are described elsewhere (2). In persistently infected cells, where nearly all the cells express viral antigens on the cell surface, cytotoxicity could be assayed as inhibition of protein synthesis. Cells were incubated with the immunotoxin for $48 \mathrm{~h}$, pulsed with ${ }^{35} \mathrm{~S}$-methionine and harvested $16 \mathrm{~h}$ later. A focal immunoassay was used to measure the production of infectious HIV by both persistently and acutely infected cells. Cells were incubated with the immunotoxin for 24 to $48 \mathrm{~h}$, washed and transferred to monolayers of HeLa-CD4+ cells $(8,9)$. One day later the monolayers were washed, then incubated for an additional two days. The monolayers were then fixed with ethanol and stained with human anti-HIV serum and peroxidase conjugated goat anti-human immunoglobulin. Foci were visualized with the colorimetric substrate aminoethylcarbazol.

Cell surface antigen expression: Flow cytometry was used to study the expression of HIV antigens on the cell surface (2). Cells were placed in phosphate buffered saline containing $1.0 \%$ bovine serum albumin and $0.01 \%$ sodium azide. Cells were incubated in the test antibody at $10 \mu \mathrm{g} / \mathrm{mL}$ for $1 \mathrm{~h}$, washed and stained with fluorescein conjugated goat anti-mouse or human immunoglobulin for $1 \mathrm{~h}$ and washed. Five thousand cells 
TABLE 2

Antibody effect on immunotoxin activity

\begin{tabular}{ccc}
\hline Antibody & Fluorescence* & \% Cytotoxicity \\
\hline$T 7$ & 10 & 0 \\
924 & 195 & 86 \\
41.1 & 13 & 85 \\
110.1 & 30 & 16 \\
\hline
\end{tabular}

-5000 H9/NL4-3 cells were examined by flow cytometry. The value presented is the peak (mode) fluorescence; 'Percentage inhibition of protein synthesis (compared with the control immunotoxin) of H9/NL4-3 cells by immunotoxins constructed with the indicated antibodies coupled to ricin A chain. Immunotoxins were tested at $2 \mu \mathrm{g} / \mathrm{mL}$

TABLE 3

Virus effect on immunotoxin activity

\begin{tabular}{lcc}
\hline HIV strain & Fluorescence* $^{*}$ & \% Inhibition $^{\dagger}$ \\
\hline Uninfected cells & 13 & NT \\
NL4-3 & 40 & 97 \\
NY5 & 22 & 68 \\
Z2 & 135 & 0 \\
Ala & 18 & 60
\end{tabular}

*5000 H9 or A3.01 cells infected with the indicated strain of human immunodeficiency virus (HIV) were examined by flow cytometry using the polyclonal human anti-gp 160. The value presented is the peak (mode) fluorescence: ${ }^{\dagger}$ Inhibition of the number of HIV-infectious centres by the polyclonal human anti-gpl60-ricin A chain immunotoxin compared with the number of infectious centres in the absence of the immunotoxin; NT not tested

TABLE 4

Characteristics of immunotoxin-resistant variants selected from persistently HIV-infected cell lines

\begin{tabular}{lllccccc}
\hline Cell line & $\begin{array}{c}\text { Cells of } \\
\text { origin }\end{array}$ & Immunotoxin & HIV genome & HIV mRNA & $\begin{array}{c}\text { Protein } \\
\text { expression }\end{array}$ & \multicolumn{2}{c}{$\begin{array}{c}\text { Envelope protein surface } \\
\text { Mutated }\end{array}$} \\
\hline Parent & H9/NL4-3 & None & + & + & + & + & + \\
Infectious
\end{tabular}

HIV Human immunodeficiency virus; RAC Ricin A chain

were analyzed for fluorescent intensity on a Becton Dickinson FACStar (California).

Western blots: Cells were lysed and run on SDS-PAGE, blotted onto nitrocellulose, then incubated with affinity purified human anti-gp 160 antibodies. Immunoreactive bands were detected with ${ }^{125}$ I-protein A (10).

\section{RESULTS AND DISCUSSION} Antibody and virus effects on immunotoxin action: We have clearly demonstrated in other publications that many, but not all, anti-gp160 antibodies can function as immunotoxins when coupled to RAC (1-3). It is clear that the antibody must bind to an epitope that is exposed on the surface of the infected cell. If there is no cell surface binding, the immunotoxin cannot function. However, we have found that the efficacy of the immunotoxin is not always related to the degree of cell surface binding. This is demonstrated in Table 2. Antibody 41.1 bound to the cell surface only marginally, yet functioned as well as an immunotoxin as antibody 924, which was highly expressed at the cell surface. Conversely, antibody 110.1 , which bound to the cells moderately well, was ineffective as an immunotoxin. We termed this phenomenon the antibody effect and have demonstrated that this was not a function of the avidity of the antibody. This has also been observed with immunotoxins directed against other target antigens and may be a function of the proximity of the epitope to the cell surface (11). If proximity is an important determinant of the antibody effect, then these immunotoxins may be used to map the topology of gp120 as expressed on the surface of infected cells (and presumably on the surface of virions). The data would then indicate that the V3 loop lies close to the cell membrane and would explain the surprisingly good efficacy of anti-gp41 immunotoxins.

We have also found that different strains of virus have different degrees of susceptibility to an immunotoxin. Paradoxically, this effect is most pronounced in virus strains that produce intense cell surface fluorescence and are minimally susceptible to the immunotoxin. As shown in Table 3, cells infected with strain Z2 stained brightly, yet were resistant to the effect of the immunotoxin. This effect, which we term the virus effect, most likely represents the balance between virus secretion and antigen internalization. Cells that stain very brightly may be producing large quantities of budding virus. This virus then binds the immunotoxin and prevents it from reaching the smaller quantity of antigen that is internalized. We have observed this effect with murine retroviruses as well. The suggestion that the ratio of secreted virus to internalized antigen can vary with different strains of HIV within the same cell type indicates the complexity of the virus/host cell relationship.

Immunotoxin-resistant Hrv variants: We have used immunotoxins to select persistently infected cell lines for variants that can resist immunotoxin action. We 


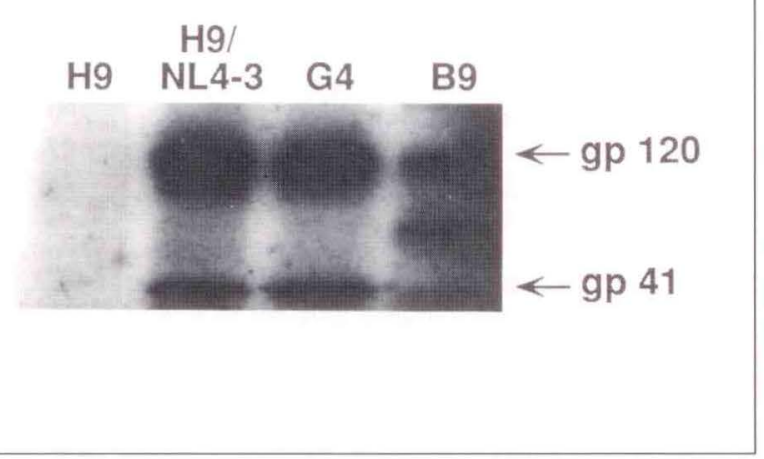

Figure 1) Western blot of immunotoxin resistant variant cells: cell lysates were run on SDS-PAGE, blotted onto nitrocellulose and detected with anti-gp160 antibodies. H9 cells were uninfected, H9/NL4-3 were the parental cells of the variants, and G4 and $B 9$ the immunotoxin-resistant variant cells. Bands corresponding to the full length gp 120 and gp41 are seen in both the parent and the variants. B9 also contains an unidentified band migrating between the two, which may represent a gp120 or gp160 degradation product

have previously shown that two different types of variants can be selected: those failing to express any viral proteins and those in which the expression of the envelope protein is specifically altered (12). In our initial report, the variants with altered envelope expression had a mutation in the envelope gene that resulted in truncation of gp41, which in turn altered the processing of the envelope protein and the intracellular routing of the virions. We have now performed additional selections as summarized in Table 4. Cell lines $10 \mathrm{E}$ and $4 \mathrm{~F}$ were described in the previous publication and represent examples of each of the two classes of variants. Cell line C9 does not express HIV proteins because it has lost the integrated provirus from its genome. G4 represents a class of variants that have a completely normal envelope gene, but do not express the protein at the cell surface. As indicated in the Western blot shown in Figure 1, G4 produces and processes full length gp 120 and gp41. We have sequenced the entire gene, and it is identical to the gene in the parental cells. Yet, the envelope protein is not expressed at the cell surface. Most likely there is a mutation in the cell line carrying this virus, and this affects the processing of the protein. Yet another type of variant is exemplified by clone 4 . As opposed to the other immunotoxin resistant variants that do not produce infectious virus, these cells produce high levels of infectious virus. The alteration in the expression of the HIV envelope in clone 4 that allows for immunotoxin resistance, yet retains infectious properties, has not been fully elucidated. By using immunotoxins to select for variant HIV-infected cells, we have been able to produce a series of alterations in either the virus or the cell carrying the virus. These have been extremely informative in defining the processing of the HIV-envelope protein (12).

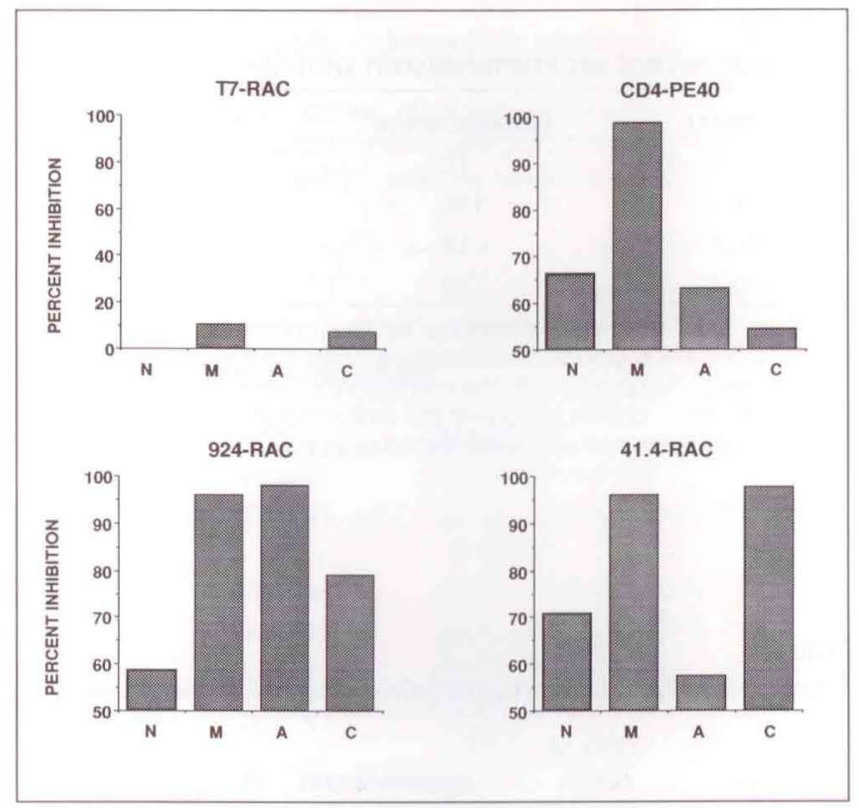

Figure 2) Effects of lysosomal inhibitors on immunotoxin function. The cytotoxic effect of suboptimal concentrations 10.05 $\mu \mathrm{g} / \mathrm{mL}$ ) of anti-human immunodeficiency virus immunotoxins (CD4-PE40, 924-ricin A chain and 41.4-ricin A chain) was measured in the presence or absence of lysosomal inhibitors. The inhibitors are indicated as follows: $N$, none; $M$, monensin (50 $n M)$; A, ammonium chloride (3.3 mM); C, chloroquine (33 $\mu \mathrm{M})$. The data are given as percentage inhibition of protein synthesis

Effect of soluble CD4 on anti-gp41 immunotoxins: We have recently reported that incubation of HIV-infected cells with soluble CD4 greatly enhances the efficacy of anti-gp41, but not anti-gp120, immunotoxins (3). This effect is due to two different processes. The first is the phenomenon of $\mathrm{CD} 4$ stripping of gp120 from gp41 $(13,14)$, which results in an increase in exposure of gp41 epitopes on the cell surface and a decrease in gp120. The second effect is that incubation with soluble CD4 enhances the rates of internalization of both gp 120 and gp41. These two effects are additive for gp41, resulting in enhanced efficacy of anti-gp41 immunotoxins. For gp120, the effects cancel each other out, resulting in no real change in efficacy of anti-gp120 immunotoxins. These observations have obvious therapeutic implications. They also demonstrate that binding of the envelope protein to its natural ligand can influence the cellular trafficking of the envelope protein.

Effects of lysosomal inhibitors on immunotoxin activity: Once an immunotoxin is internalized, the path it follows determines its ability to kill the target cell (15). Intracellular routing may return it to the cell surface, send it in a retrograde fashion through the protein secretory pathway, or direct it to the lysosomes where it will be degraded (16). To function, the toxic moiety must eventually be present within the cytosol. Characteristics of both the immunotoxin and the target antigen determine what proportion of the immunotoxin will follow each pathway. Drugs that inhibit lysosomal deg- 
radation of the immunotoxin can be used to determine whether the lysosomal pathway plays an important role in the routing of a particular immunotoxin. They may also be used to enhance the pharmacological effects of the immunotoxin. We have tested the effects of three different lysosomal inhibitors on anti-HIV immunotoxins. Ammonium chloride alkalinizes the lysosome, inhibiting enzyme function. Chloroquine stabilizes the lysosomal membrane, preventing transfer across it. Monensin reduces ion flux across membranes and inhibits transport into lysosomes, as well as interfering with intracellular trafficking of endosomes and secretory vesicles. As shown in Figure 2, all three agents enhanced the efficacy of 924-RAC, monensin and chloroquine enhanced 41.4-RAC, but only monensin enhanced CD4-PE40. These data demonstrate that the lysosomal pathway plays an important role in the intracellular routing of antibody-ricin immunotoxins, but probably not of CD4-PE40.

\section{CONCLUSIONS}

Because anti-HIV immunotoxins must both bind to the surface of HIV-infected cells and be internalized to

ACKNOWLEDGEMENTS: We thank Susan Smaus and Carole Smaus for secretarial assistance, Robert Evans for photography, and Don Batts of Upjohn Laboratories for soluble CD4 and CD4-PE40.

\section{REFERENCES}

1. Pincus SH, Wehrly K, Chesebro B. Treatment of HIV tissue culture infection with monoclonal antibody-ricin A chain conjugates. J Immunol 1989;142:3070-5.

2. Pincus SH, Cole RL, Hersh EM, et al. In vitro efficacy of anti-HIV immunotoxins targeted by various antibodies to the envelope protein. J Immunol 1991;146:4315-24

3. Pincus SH, McClure J. Soluble CD4 enhances the efficacy of immunotoxins directed against gp4l of the human immunodeficiency virus. Proc Natl Acad Sci USA 1993:90:332-6.

4. Chaudhary VK, Mizukami T, Fuerst TR, et al. Selective killing of HIV-infected cells by recombinant human CD4-Pseudomonas exotoxin hybrid protein. Nature 1988:335:369-72.

5. Berger EA, Clouse KA, Chaudhary VK, et al. CD4-Pseudomonas exotoxin hybrid protein blocks the spread of human immunodeficiency virus infection in vitro and is active against cells expressing the envelope glycoproteins from diverse primate immunodeficiency retroviruses. Proc Natl Acad Sci USA 1989;86:9539-43.

6. Till MA, Ghetie V, Gregory T, et al. HIV-infected cells are killed by rCD4-ricin A chain. Science 1988;242:1166-8.

7. Pincus SH, Wehrly K. AZT demonstrates anti-HIV-1 activity in persistently infected cell lines: Implications for combination chemotherapy and immunotherapy. J Infect Dis 1990; $162: 1233-8$.

8. Pincus SH, Wehrly K, Chesebro B. Use of a focal infectivity assay for testing susceptibility of HIV to function, they may be used as probes of the cellular trafficking of the target antigens. That these immunotoxins function at all is the strongest indication that there is a recirculating pool of envelope protein that re-enters the cell after being displayed on the cell surface. A number of factors, including the strain of HIV and the presence of a soluble form of the HIV-receptor $\mathrm{CD} 4$, can influence the degree of internalization. Once internalized, the lysosomal pathway is an important route in the processing of antibody immunotoxins bound to the envelope protein. Using the immunotoxins to select variants, we have identified mutations within both the virus and the cell that can affect the processing of the envelope protein and alter the secretion of the virus. All of these data indicate the complexity of the relationship between HIV and the cell it inhabits.

The data described in this article also have important therapeutic implications. The ability to enhance the efficacy of antibody immunotoxins with soluble CD4 and with lysosomal inhibitors, without a consequent increase in nonspecific toxicity, should augment any therapeutic utility of the immunotoxins. Initial clinical trials with anti-HIV immunotoxins are in progress.

antiviral agents. BioTechniques 1991;10:336-42.

9. Chesebro B, Wehrly K. Development of a sensitive quantitative focal assay for human immunodeficiency virus infectivity. J Virol 1988;62:3779-88.

10. Pincus SH, Cole RL, Kamanga-Sollo E, Fischer SH. Interaction of group B streptococcal opacity variants with the host defense system. Infect Immun 1993;61:3761-8.

11. May RD, Finkelman FD, Wheeler HT, Uhr JW, Vitetta ES Evaluation of ricin A chain-containing immunotoxins directed against different epitopes on the delta-chain of cell surface-associated IgD on murine B cells. J Immunol 1990; 144:3637-42.

12. Pincus SH, Wehrly K, Tschachler E, Hayes SF, Buller RS Reitz M. Variants selected by treatment of human immunodeficiency virus-infected cells with an immunotoxin. J Exp Med 1990;172:745-57.

13. Sattentau QJ, Moore JP. Conformational changes induced in the human immunodeficiency virus envelope glycoprotein by soluble CD4 binding. J Exp Med 1991;174:407-15.

14. Berger EA, Lifson JD, Eiden LE. Stimulation of glycoprotein gp120 dissociation from the envelope glycoprotein complex of human immunodeficiency virus type 1 by soluble CD4 and CD4 peptide derivatives: Implications for the role of the complementaritydetermining region 3-like region in membrane fusion. Proc Natl Acad Sci USA 1991;88:8082-6.

15. May RD, Wheeler HT, Finkelman FD, Uhr JW, Vitetta ES. Intracellular routing rather than cross-linking or rate of internalization determines the potency of immunotoxins directed against different epitopes of sigD on murine B cells. Cell Immunol 1991;135:490-500.

16. Olsnes S, Sandvig K, Peterson OW, van Deurs B. lmmunotoxins: Entry into cells and mechanisms of action. Immunol Today 1989;10:291-5. 


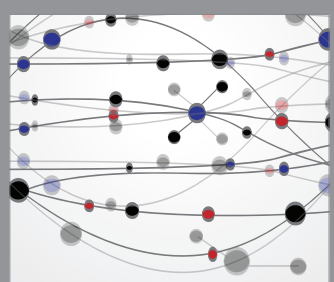

The Scientific World Journal
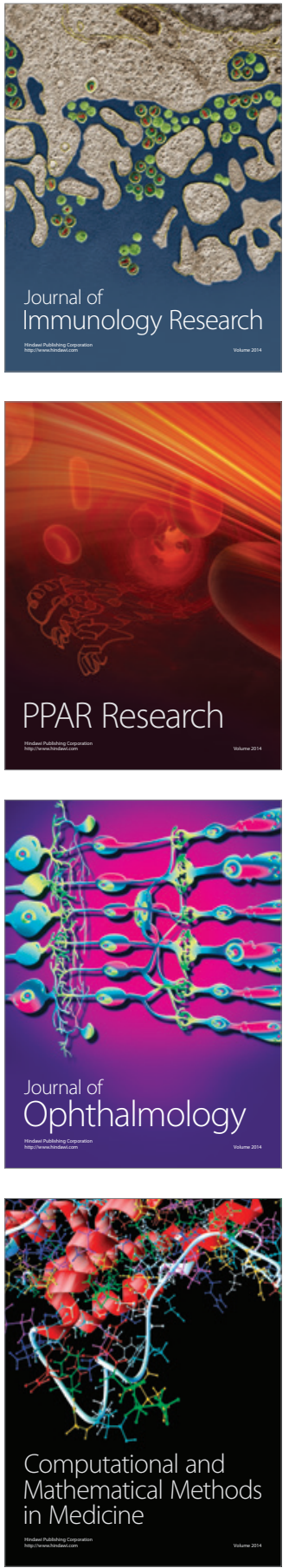

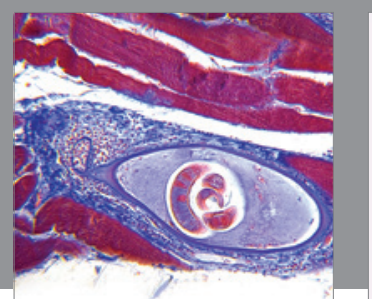

Gastroenterology Research and Practice

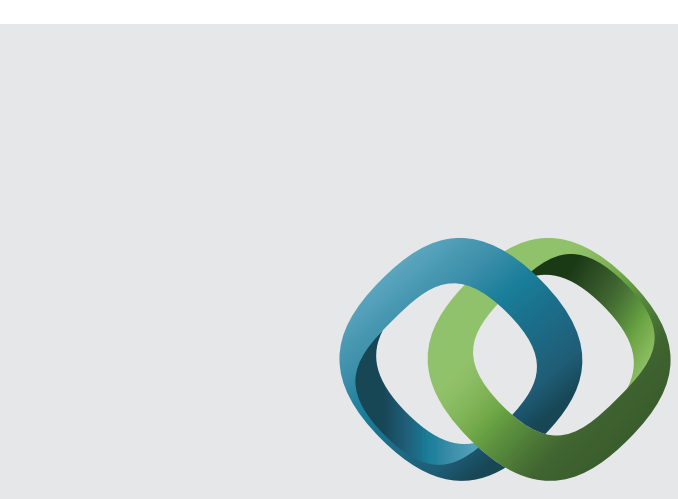

\section{Hindawi}

Submit your manuscripts at

http://www.hindawi.com
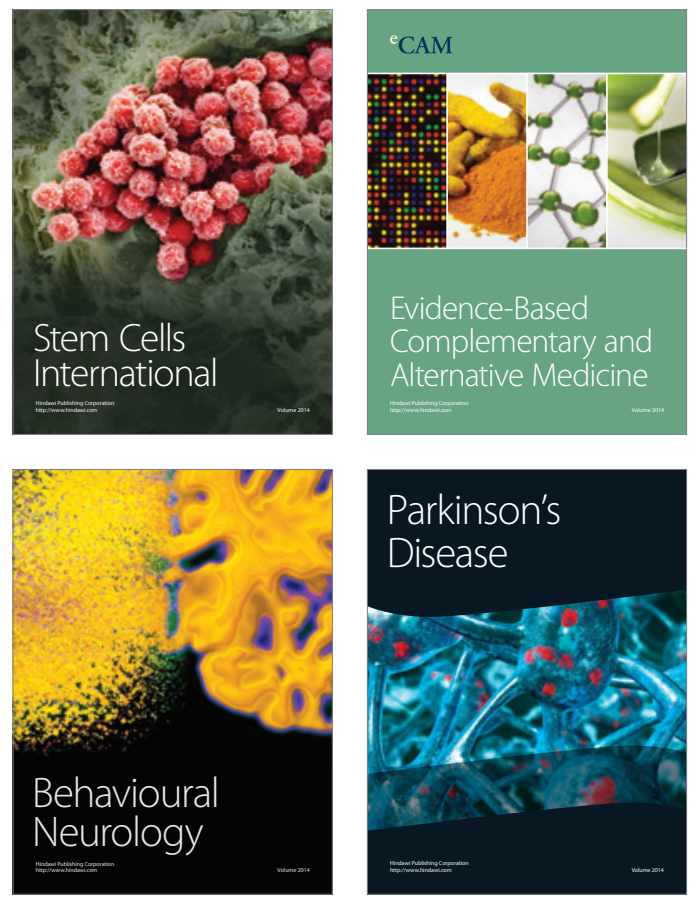
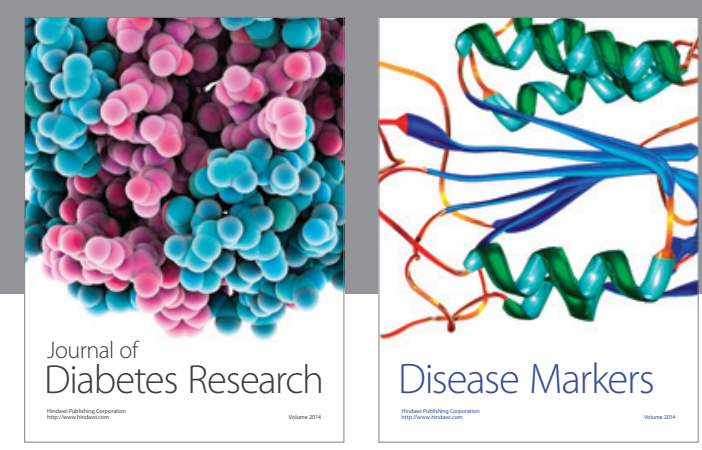

Disease Markers
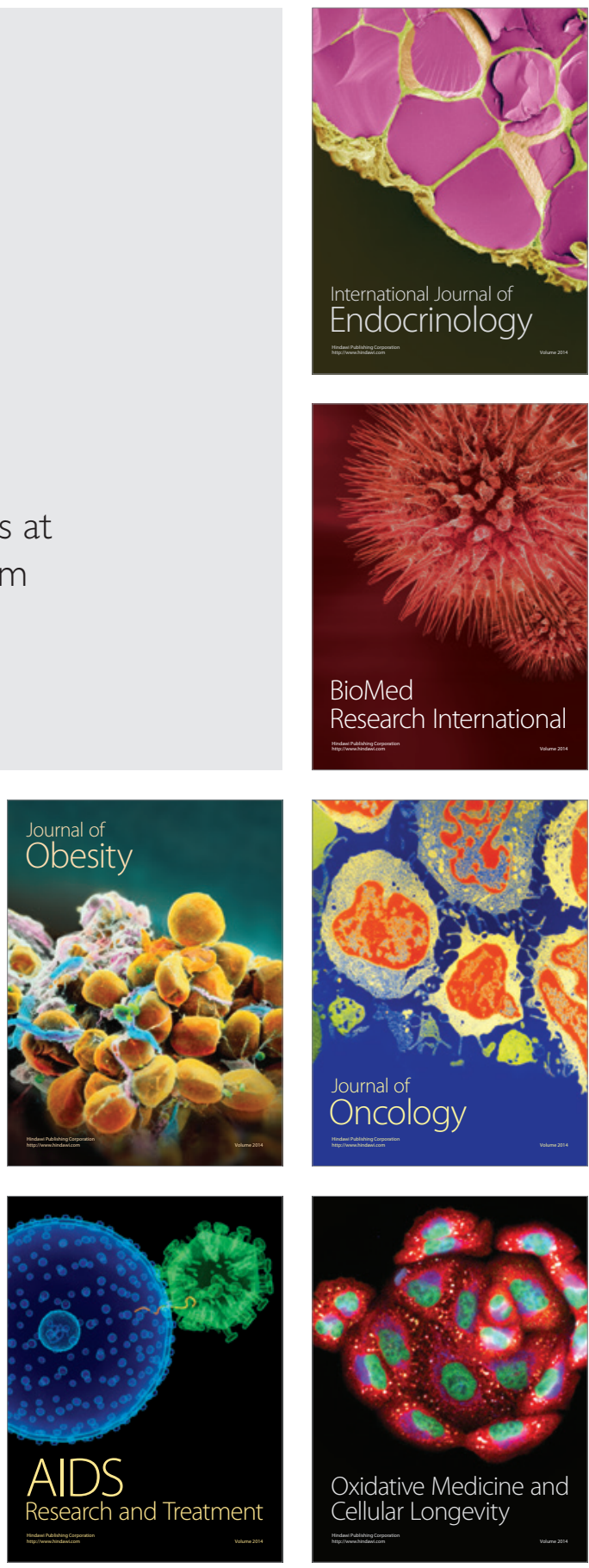